Uniwersytet Gdański

Wydział Filologiczny

Instytut Rusycystyki i Studiów Wschodnich

tel. +48585233038

e-mail: liliana.kalita@ug.edu.pl

\title{
Dryfowanie ku szczęściu? O twórczości filmowej Borysa Chlebnikowa
}

Słowa kluczowe: kino rosyjskie, Borys Chlebnikow, Rosja współczesna, mentalność rosyjska

Wśród najciekawszych współczesnych reżyserów rosyjskich, obok postaci takich jak Siergiej Łoźnica, Andriej Zwiagincew, czy Andriej Smirnow, znajduje się również Borys Chlebnikow, przedstawiciel kina autorskiego, wnikliwy obserwator rosyjskiej rzeczywistości i duszy zaludniających ją bohaterów. Jego filmy sytuowane są w nurcie arthouse, pokazywane na festiwalach filmowych, dostrzegane przez krytyke, jednak rzadko prezentowane na antenie kanałów telewizyjnych. Polscy widzowie z filmami Chlebnikowa mieli okazję zetknąć się na 8. Festiwalu Filmów Rosyjskich „Sputniku nad Polską" w 2015 roku, gdzie pokazywane były dwa obrazy: Zanim noc nas nie rozdzieli (Пока ночь не разлучит, 2012) oraz Dlugie szczęśliwe życie (Долгая счастливая жизнь, 2013).

Borys Chlebnikow urodził się w 1972 roku w Moskwie. Przez dwa lata studiował biologię, jednak zrezygnował z niej na rzecz moskiewskiej szkoły filmowej, gdzie studiował scenopisarstwo i krytykę filmową. Wydaje się jednak, że z zainteresowania naukami przyrodniczymi Chlebnikow nigdy całkowicie nie zrezygnował. Przyroda jest ważną częścią warstwy wizualnej jego filmów i ich wymowy ideowej. Znalazło ono także ujście w sposobie prowadzenia narracji. Chlebnikow, niczym naukowiec pod mikroskopem, 
niespiesznie i drobiazgowo ogląda świat, rejestrując zachodzące w nim procesy i przeobrażenia, przyjmując na siebie rolę pośrednika w przekazywaniu widzowi stanu rzeczywistości i wyraźnie ukrywając osobiste ingerencje, co jest oczywiście przemyślaną autorską strategią. Chlebnikow zadebiutował krótkometrażowym filmem, zrobionym razem z Aleksiejem Popogrebskim pt. Мимоход (1997), w 2000 roku również z Popogrebskim zrealizował kolejny krótkometrażowy film pt. Хитрая лягушка, by wreszcie w 2003 roku spróbować swoich sił w fabule. Pierwszy fabularny obraz nosił tytuł Kokmeбел (tu także współreżyserem był Popogrebski). Był to film drogi, osnuty wokół pieszej wyprawy ojca i syna z Moskwy do tytułowej miejscowości na Krymie, podczas której podróżnicy konfrontują się z napotkanymi po drodze ludźmi, towarzyszy im też opowieść o cudownej górze. Film zdobył nagrody na festiwalach w Moskwie i Karlowych Warach W 2006 roku na ekranach pojawił się pierwszy samodzielny film Chlebnikowa pt. Dryfowaniе (Свободное плавание), który z kolejnymi filmami: Zwariowana poтос (Сумасшедшая помощь, 2009) і Długie szczęśliwe życie stanowią trylogię o nieuchronności losu. Borys Chlebnikow ma w swojej filmografii również m.in. seriale telewizyjne, tj. Churchill (Черчилль, 2009), Bez świadków (Без свидетелей, 2012) czy Zatroskani, czyli umiłowanie zła (Озобоченнье, или Любовь зла, 2015).

Chlebnikow należy do artystów pracujących chętnie z tymi samymi aktorami i scenarzystami. I to oni w nie mniejszym stopniu niż reżyser wpływają na ostateczny kształt filmu. Stałym współscenarzystą Chlebnikowa jest Aleksander Rodionow, zaś aktorami - Aleksander Jacenko, Jewgienij Sytyj czy Anna Kotowa. Powierzanie głównych ról tym samym aktorom pozwala ukonkretnić i pogłębić opowiadane historie. Widz, obserwując zachowania, reakcje i wybory bohatera kreowanego przez Jacenkę czy Sytego ma wrażenie, że uczestniczy w życiu tego samego człowieka na różnych jego etapach, towarzyszy mu przez lata w jego drodze życiowej, która jest podlegającym zmianom i oddziaływaniom nierzadko sprzecznych okoliczności procesem, a nie skończoną historią. Swoją filozofię pracy reżysera Chlebnikow wyłożył w jednym z wywiadów, mówiąc: „myślę, ze trzeba opowiadać historie tak, jak masz na to ochotę. Przecież każdy człowiek jest interesujący tylko wtedy, kiedy mówi swoim językiem i mówi to szczerze. Nie można zdradzać samego siebie" [http://snimifilm.com/intervju/boris-khlebnikov-v-nashei-stra ne-trudno-nauchitsya-professii].

Krytycy filmowi dla twórczości Borysa Chlebnikowa szukają analogii w kinie takich przedstawicieli stylu autorskiego, jak m.in. Otar Iosseliani, Jim Jarmusch, czy Aki Kaurismaki, z zastrzeżeniem jednak, iż nie może być mowy o imitacji cudzej metody, podobieństwo zauważalne jest natomiast 
w niuansach: „reżyserów zbliża zainteresowanie nieciekawym życiem, podejście do humoru jako środka ratującego przed codzienną rzeczywistością, jak również «niemota» ich filmów, współbrzmiąca z niezdarnością świata «maleńkiego człowieka»" [Мерзлякова, online].

Zainteresowanie Chlebnikowa „małym człowiekiem” i jego losem widoczne jest już w debiutanckim filmie reżysera, którego tytuł - Dryfowanie - to metafora nie tylko sytuacji Rosjanina w postsowieckim społeczeństwie, ale i każdego człowieka w realiach płynnej ponowoczesności, który, by odwołać się do ustaleń Zygmunta Baumana, nie porusza się już w czasie i przestrzeni, zmierzając do konkretnego celu, ale unoszony jest kapryśnymi falami losu w nieznane. Reżyser umieszcza akcję swojego filmu na rosyjskiej prowincji, w zniszczonym, niewielkim miasteczku nad Wołgą, w którym pracę mieszkańcom zapewniała miejscowa fabryka, jednak jej zamknięcie stawia pracowników przed koniecznością wzięcia odpowiedzialności za swój los. Głównym bohaterem jest 20-letni Lonia, dla którego brak pracy nie jest dramatem, ale okazją do sprawdzenia siebie w różnych życiowych okolicznościach. Jak zaznaczył sam reżyser, fabuła filmu skonstruowana jest „według logiki bajki o trzech drogach. Bohater filmu [...] styka się z różnymi ludźmi, nieustannie zmienia miejsce pracy. Traktuje to jako osiągnięcie: nie tyle chce zarabiać pieniądze, co zajmować się czymś ważnym. Jest to film o rodzeniu się w człowieku przekonania o możliwości wyboru, prawa wyboru i równocześnie problemu wyboru' [http://www.vokrug.tv/person/show/boris_khleb nikov/]. Chlebnikow nie pokazuje wewnętrznych zmagań bohatera, nie wiemy dokładnie co go motywuje do poszukiwania dla siebie odpowiedniego miejsca, potrzeba zmiany w życiu dwudziestolatka sugerowana jest humorystycznymi scenami wizyt Loni $\mathrm{w}$ biurze zatrudnienia. Zgodnie z bajkową konwencją bohater podejmuje się trzech prac: sprzedawcy obuwia na rynku, tynkarza (rezygnuje $\mathrm{z}$ zadania nie dojechawszy na miejsce) i wreszcie robotnika w brygadzie remontującej droge nieopodal jego domu. Praca nie wymaga wykonywania skomplikowanych czynności, jest natomiast okazją do zetknięcia się z innymi, członkowie brygady bowiem to osobliwe jednostki, z których każda stanowi swoisty mikroświat, chociaż jakość ich robót pozostawia wiele do życzenia. W brygadzie jest człowiek-wiadro (Piotr Zajczenko) i człowiek-tłuczek (Borys Pietrow), jednak najważniejszą postacią jest brygadzista Rosłow (Jewgienij Sytyj) - domorosły filozof-gawędziarz, który widzi w Loni swojego ucznia i chętnie dzieli się z nim spostrzeżeniami na temat życia, pracy, kobiet, siebie samego. Rosłow to, podobnie jak inni robotnicy, postać tragikomiczna - gadulstwo i lenistwo oraz pozowanie na znawcę życia czyni z niego - z jednej strony - postać śmieszną, z drugiej jednak - pozwala postrzegać go ja- 
ko człowieka nieszczęśliwego, prawdopodobnie zakompleksionego, którego rozbudzone ambicje nie mają szans na realizację. Brygadzista to w pewnym stopniu typ „człowieka zbędnego”, poszukującego być może jakiejś prawdy, jednak unikającego konfrontowania swoich poglądów z innymi, czy to z powodu braku intelektualnych partnerów, czy z lęku przed ich zdyskredytowaniem.

Interesującym wątkiem filmu są relacje Loni z koleżanką mieszkającą $\mathrm{w}$ domu usytuowanym tuż przy remontowanej drodze. Ich codzienne kontakty mają wyraźny podtekst erotyczny - Lonia coraz silniej uświadamia sobie, że dziewczyna, zwana przez niego Świnią (!), nie jest mu obojętna, choć cechująca go nieporadność, brak doświadczenia w obcowaniu z płcią przeciwną, czyni te spotkania bardziej śmiesznymi i żałosnymi, niż romantycznymi. Problemy ze zbliżeniem się obojga młodych ludzi do siebie, wynikające zapewne z konieczności odgrywania określonych w danej społeczności ról, doskonale oddają toczące się między nimi dialogi, ograniczające się do równoważników zdań, o bardzo emocjonalnym charakterze, jednak pozbawione głębszej treści. Sprowadzają się one najczęściej do wymiany zdań: „А чё?”, „Работаю, че, а ты-то че?!”. Jak zauważył Aleksander Iwanow, w filmie Dryfowanie reżyserowi „wstrząsająco udało się połączyć groteskę z rzeczywistością: z jednej strony wszyscy bohaterowie jego obrazu są absurdalni i komiczni, z drugiej jednak, są po mistrzowsku wyjęci z realnego życia" [Иванов, online].

Film ma otwarte zakończenie. Finałowa scena to kolejny wybór, przed którym staje bohater na drodze do poszukiwania, czy kształtowania własnej tożsamości, co nadaje opowieści, poprzez powtarzalność pewnych sytuacji, wymiaru uniwersalnego. Wymowę ideową losu człowieka, pokazanego na przykładzie historii Loni, wzmacniają środki filmowe - długie, statyczne ujęcia, niespieszny montaż, przybrudzony obraz, oszczędne ruchy postaci, ubogie dialogi tworza swoisty klimat obrazu, charakterystyczny dla maniery twórczej Chlebnikowa. W krytyce, poświęconej filmowi, zwraca się również uwagę na odniesienia do innych filmów, m.in. Noża w wodzie Romana Polańskiego [Гаврилова, online], co bez wątpienia świadczy o tym, w jakiej tradycji chciałby Chlebnikow być sytuowany jako twórca. Dryfowanie otrzymało nagrodę za reżyserię na festiwalu „Kinotawr” w Soczi oraz dwie nagrody krytyków filmowych i prasy - za film i reżyserię.

Kolejny film Borysa Chlebnikowa pt. Zwariowana pomoc trudno jest przyporządkować do określonego gatunku, kwalifikuje się go bowiem zarówno jako tragikomedię, arthouse, czy też dramat, a nawet komedię, choć najczęściej mowa po prostu o filmie obyczajowym. Gazeta „Moskiewski Komsomolec" na VII Moskiewskim Festiwalu Filmowym przyznała obrazo- 
wi Chlebnikowa nagrodę „za dobry film, zrealizowany w niedobrym czasie”. Reżyser na przykładzie relacji społecznych, panujących na jednym z moskiewskich blokowisk, prezentuje obraz mieszkańców współczesnej rosyjskiej metropolii, ludzi zamkniętych w swoich domach, pozbawionych potrzeby kontaktu z innymi, obojętnych na dziejące się wokół nich zło, zatroskanych jedynie o sprawy materialne. Głównym bohaterem jest Białorusin Jewgienij (Jewgienij Sytyj), który ze wsi Krupki udaje się do rosyjskiej stolicy w poszukiwaniu pracy. Mężczyzna jest typem człowieka ufnego, naiwnego, małomównego i nie potrafiącego dbać o swoje sprawy, cechuje go bierność i skłonność do poddawania się temu, co przynosi los. Na peryferiach Moskwy zostaje pobity, ograbiony z pieniędzy, dokumentów, ubrań i pozostawiony samemu sobie. Na swojej drodze spotyka przypadkiem byłego inżyniera, który zabiera go do swojego domu. Jak się okazuje, bardzo ludzka reakcja Inżyniera (w tej roli Siergiej Drejden), to wyjątek wśród lokalnej społeczności, powodem jej zaś jest szaleństwo bohatera. Inżynier owładnięty jest przekonaniem, że na świecie zapanowało zło, a on wie jak z nim walczyć, uosobieniem zła jest natomiast dzielnicowy. Zdaniem Inżyniera w każdym domu więziony jest człowiek, by nie mógł, kontaktując się z innymi, spełniać dobrych uczynków. Jewgienij, zafascynowany postawą swojego dobroczyńcy, wierzy w jego misję naprawy świata i staje się jego pomocnikiem. Taki schemat fabularny, jak słusznie zauważyli recenzenci i widzowie, przywołuje postacie Don Kichota i Sancho Pansy i jest źródłem rozwoju fabuły, humoru sytuacyjnego oraz postaw wobec rzeczywistości. Inżynier zaskakuje poziomem otwartości na innych, życzliwości i zaangażowania w sprawę, w którą wierzy. W konfrontacji z innymi mieszkańcami osiedla: przepełnionymi strachem, smutnymi, wiecznie spieszącymi się i nijakimi przypomina swoim zachowaniem jurodiwego, który obala społeczne normy, by wykazać ich fałsz i antyludzki charakter. Wyraźna sugestia reżysera, iż dobro czynić może jedynie człowiek szalony jest gorzką konstatacją o czasach współczesnych, zapewne nie tylko w Rosji.

Dla Jewgienija z kolei spotkanie z Inżynierem jest przygodą życia, wyrwaniem go z marazmu dotychczasowej, pełnej powierzchownych kontaktów międzyludzkich i codziennych jednostajnych czynności, egzystencji. Bycie pomocnikiem Inżyniera, towarzyszenie mu w ratowaniu ludzkości przed brakiem prawdy, dobra i piękna, nadaje życiu bohatera głębszego sensu, uświadamia, iż nie tylko praca i pieniądze są celem, do którego warto zmierzać. U Inżyniera Jewgienij poznaje jego córkę i choć kontakty z nią są szorstkie, a wzajemne porozumienie wydaje się niemożliwe, rodzi to w obojgu refleksje o ewentualnej szansie na bycie razem w zatomizowanej rzeczywistości, czego dowodem ostatnie, wizyjne, sceny filmu. 
Z metafizycznym aspektem filmu, związanym z postacią i czynami Inżyniera, kontrastuje wątek milicjanta, który oczekuje na decyzję, czy przez kolejny rok będzie wypełniał obowiązki dzielnicowego. Obraz posterunku milicji i pracujących w nim ludzi to negatywna przeciwwaga dla tych wartości, które reprezentuje szlachetny Inżynier i prostolinijny Jewgienij. Milicjanci nadużywają swojej funkcji, ignorują skargi mieszkańców, nie podejmują działań, by wyjaśnić przestępstwa i złapać ich sprawców. Dzielnicowy Godiejew, odpowiadający zdaniem Inżyniera za obecne na osiedlu zło, to z jednej strony brutalny, nie potrafiący zapanować nad agresją, bezkarny oprawca, z drugiej jednak człowiek przeżywający dramat zawodowy z powodu grożącego mu zwolnienia z pracy. Scena posiedzenia komisji, która rozstrzyga jego sprawę nawiązuje do tynianowowskiej tradycji absurdu. Przewodniczący komisji odczytując postanowienie jednocześnie wyraża żal, iż Godiejewa nie ma z nimi, choć $\mathrm{w}$ istocie znajduje się on w pomieszczeniu, w którym odbywa się posiedzenie i nawet próbuje rozmawiać z kolegami, jednak ci go nie słyszą i nie dostrzegają.

Jak zauważyła Jekaterina Altowa ,świat filmu jest dziwny, rozpadający się, niedorzeczny. [...] I mimo wszystko jest jedna, jedyna rzecz, która łączy bohaterów, jest właściwa każdemu z nich. Jest wspólny motyw, który zmusza ich do działania, a motyw ten to - samotność. Jest to coś czyniącego ich podobnymi i jednocześnie bardzo osobistego, namacalnego. Każdy przeciwstawia się mu jak może" [Альтова, online].

Próba sprostania ideałom w realnym świecie określonego systemu prawnego i politycznego, zachowania ludzkiej godności i dotrzymania danego innym słowa jest tematem kolejnego filmu Borysa Chlebnikowa pt. Dtugie szczęśliwe życie. Krytyk filmowy Jurij Gładilszczikow nazwał obraz filmem-ciosem: „siedzacc w sali kinowej nie tylko zaciskasz pieści od poczucia niesprawiedliwości, która dzieje się z bohaterem, ale również masz ochotę wedrzeć się w przestrzeń ekranu i zacząć bić po mordach" [Гладильщиков, online].

W filmie tym Chlebnikow wraca na rosyjską prowincję i na przykładzie funkcjonowania farmy rolniczej pokazuje układ stosunków pomiędzy jednostką a administracją publiczną, wspieraną przez prawników i milicję. Aleksander Jacenko wciela się tu w postać Saszy, młodego farmera z Półwyspu Kolskiego, który wydzierżawił ziemię i zatrudnił na niej mieszkańców wsi. Praca na roli i zarządzanie niezbyt pracowitymi ludźmi, nie jest łatwe, a jego ukochana Anna namawia go na życie w mieście, dlatego tė̇ gdy miejscowa kancelaria notarialna, reprezentująca administrację rządową, proponuje mu odkupienie ziemi, Sasza chętnie na to przystaje. Mieszkańcy jednak zgłaszaja protest i proszą bohatera by zmienił decyzję, obiecu- 
jąc mu swoje wsparcie. Nieoczekiwanie dla samego siebie, Sasza, mężczyzna niezbyt odważny i chętnie idący na kompromis, znajduje w sobie siłę i determinację by podjąć walkę z systemem, sprzeciwić się władzy, narażając się tym samym na ewentualne szykany i próby nacisku o charakterze kryminalnym ( $w$ gospodarstwach tych, którzy odmawiali wybuchały niespodziewanie pożary, które niszczyły zabudowę, obniżając wartość gruntu). Bohater trwa konsekwentnie w swojej decyzji nawet wtedy, gdy zostaje zdradzony i opuszczony przez rolników, którzy jeszcze niedawno stali po jego stronie. Okazuje się bowiem, że walka wymaga wysiłku i uporu, do jakiego rolnicy nie są zdolni, a obiecane pieniądze oddziałują na wyobraźnię bardziej niż perspektywa długotrwałej pracy na rzecz wspólnego dobra. Obserwujemy zatem dramat człowieka, który chciał działać z innymi i dla innych, a jednak pozostaje sam, tracąc po drodze wsparcie, ukochaną, dobre imię. Poproszony zostaje wręcz o wyjazd z wioski, bo „rację mają ci, co mają władzę", a on swoją obecnością przypomina mieszkańcom o ich nielojalności i odstępstwie od poczynionych ustaleń. Samotny, zdradzony bohater, staje do ostatecznej konfrontacji z systemem, a nierówna walka wyzwala w nim tłumioną wcześniej agresję i czyni ostatecznie mordercą. Prometejska postawa Saszy przypomina bohatera filmu Jurija Bykowa pt. Dureń; podobnie jak Dima Nikitin Sasza zwycięża jako bohater, ale przegrywa jako człowiek. Portret Rosji i Rosjan, nakreślony w filmie o ironicznym tytule Dlugie szczessliwe życie pobudza do refleksji nad ceną postawy humanitarnej, jednością i solidarnością narodu rosyjskiego oraz jego podatnością na działania manipulacyjne. Jak zauważyła Barbara Holender „film sprawia wrażenie paradokumentu. Wszystko tu tchnie prawdą. Widz przeżywa tragedię głównego bohatera z bliska. I z bliska przygląda się światu, w którym nie ma miejsca dla marzycieli i idealistów" [Hollender, online]. Efekt ten udało się reżyserowi uzyskać za sprawą pracy operatora - zdjęcia robione są cyfrową kamerą, „z ręki”. Długie szczęśliwe życie zamyka Chlebnikowowską trylogię o nieuchronności losu, a zaprezentowane w poszczególnych jej częściach spojrzenie reżysera na świat i ludzi pozwala mówić o nasilaniu się w kolejnych filmach pesymizmu i krytycznej oceny rzeczywistości.

Najnowszym pełnometrażowym filmem Borysa Chlebnikowa jest obraz Zanim noc nas nie rozdzieli, w którym reżyser przygląda się współczesnym moskiewskim celebrytom, biznesmenom, producentom filmowym, urzędnikom, młodzieży, bohaterom pierwszych stron gazet, czyli osobom, które dla wielu członków społeczeństwa rosyjskiego stanowią wzorzec intelektualny i moralny. Pomysł filmu zaczerpnięty został z artykułu w czasopiśmie „Большой Город”. Tekst prezentował podsłuchane w restauracji „Pusz- 
kin" rozmowy gości. Ten koncept wydał się reżyserowi znakomitym punktem wyjścia do pokazania relacji społecznych i mentalności Rosjan XXI wieku. Obserwujemy nie tylko eleganckich klientów restauracji, ale także problemy uczuciowe i osobiste kelnerów ( $\mathrm{w}$ tych rolach stali aktorzy Aleksander Jacenko i Jewgienij Sytyj), a także kłopoty pracowników kuchni, obsługiwanej w całości przez imigrantów z byłych radzieckich republik i przedstawicieli „kaukaskich narodowości”.

W filmie wzięły udział (jedynie za procent od zysku) rosyjskie gwiazdy, np. Siergiej Sznurow, Wasilij Utkin, Alena Dolecka, Agnija Kuzniecowa i inni, a ich dialogi tworzone były w dużej mierze na żywo, tuż pod okiem kamery, co pozwala mówić o filmie jako eksperymencie. Film nie tworzy spójnej konstrukcji problemowej, ale jest łańcuchem luźnych scen, a z rozmów bohaterów wyłania się ich stosunek do innych i życiowe priorytety. Postawione przed gośćmi restauracji lustro odzwierciedla potrzeby i ideały rozmówców: Większość tematów rozmów dotyczy pieniędzy, własnego wizerunku i społecznego prestiżu. Spod eleganckich garniturów i wystylizowanych fryzur wychodzą osobowości miałkie, nie mające nic ciekawego do powiedzenia, patrzące na życie powierzchownie i egocentryczne. Przeciwwagą dla rozmów toczących się na sali jest poniekąd obraz kucharzy, a szczególnie ich szefa, który próbuje wyciągnąć z aresztu jednego z kucharzy, przypadkowo aresztowanego przez milicję. Determinacja mężczyzny, jego sposób rozwiązania problemu, a przy tym opanowanie i panowanie nad załoga sprawiają, że to on staje się wzorem do naśladowania. Ciekawe relacje łącza kelnerów restauracji. Dima i Wołodia, choć mają podobne problemy (jeden z żoną, drugi z kochanką) wyraźnie unikają siebie nawzajem, co sprawia, że uwaga widza w dużym stopniu skierowana jest na ich kontakty w oczekiwaniu jakiegoś punktu kulminacyjnego. Reżyser czyni zadość oczekiwaniom widza, przenosząc ten punkt na koniec filmu, kiedy to zwykłe nieporozumienie staje się bodźcem do bójki nie tylko kelnerów, ale wszystkich zgromadzonych w sali jadalnej. Gościom w nienagannie dobranych strojach i wystylizowanych fryzurach puszczają hamulce i dają o sobie znać pierwotne instynkty: złość, frustracja, kompleksy, strach i potrzeba górowania nad innymi. Bartosz Staszczyszyn w recenzji filmu podkreślił, iż Chlebnikow „proponuje nam ponurą diagnozę na temat ludzi - żałosnych, małostkowych i pozbawionych jakiejkolwiek szlachetności", choć jednocześnie zaznaczył, że obraz, mimo ciekawego tematu, pozbawiony jest ,gatunkowego ciężaru i intelektualnej przenikliwości" [Staszczyszyn, online]. Istotnie, widz, oczekujący pogłębionej diagnozy społecznej, może czuć się rozczarowany, jednak Chlebnikow wydaje się w tym filmie być konsekwentny wobec obranych już wcześniej autorskich strategii, bazujących m.in. na zaintere- 
sowaniu nie tyle tym, jacy Rosjanie są dzisiaj (mimo krytycznej wymowy filmów reżyser podchodzi do swoich bohaterów z dużą dozą zrozumienia), ale co utracili w wyniku transformacji ekonomicznych i co tracą nadal. Takie spojrzenie na rzeczywistość wpisuje się w ogólnie panujące tendencje we współczesnym kinie rosyjskim, dla którego - jak zauważył Grzegorz Szymczak - „obiektem zainteresowania jest człowiek oraz jego złożona natura drzemiące w nim zło lub wyrzuty sumienia, gotowość do poświęceń w imię miłości, solidarności bądź elementarnej sprawiedliwości" [Szymczak, online]. Chlebnikow pokazuje Rosje bez moralizatorstwa i nachalnego dydaktyzmu, Rosję, w której pełno jest cierpienia, niesprawiedliwości i blichtru, ale czyż nie tego pragną widzowie, próbujący zgłębić „zagadkową dusze rosyjską"?

\section{Literatura}

Bauman Z., 2004, Ponowoczesność jako źródto cierpień, Warszawa.

Hollender B., Dtugie szczęśliwe życie - recenzja filmu, [online], http://www.rp.pl/ artykul/1076998-Dlugie-szczesliwe-zycie---recenzja-filmu.html\#ap-1 [28.09.2016].

Staszczyszyn B., Rosja od kuchni, [online], http://www.filmweb.pl/reviews/Rosja+ od+kuchni-14172 [28.09.2016].

Szymczak G., Rosyjskie kino trzyma się mocno, [online], http://www.tygodnik przeglad.pl/rosyjskie-kino-rzyma-sie-mocno/ [28.09.2016].

Альтова Е., Сеансу отвечают: Сумасшедшая помощ, [online], http://seance.ru/ n/41-42/films2009/pomosch41-42/sumasshedshaya-pomosch/\# $[28.09 .2016]$.

Борис Хлебников, [online], http://www.vokrug.tv/person/show/boris_khlebnikov/, [28.09.2016].

Гаврилова М., Свободое плавание: русский народный транквилизатор, [online], http://www.kinokadr.ru/articles/2006/11/15/svobodnoe.shtml, [28.09.2016].

Гладильщиков Ю., Идет охота на волков, [online], http://www.mn.ru/culture/ film/85818 [28.09.2016].

Иванов А., Моя пришибленная Русь, [online], http://www.volgogradru.com/the me/info/culture/movie/kino/84536.pub, [28.09.2016].

Мерзлякова А., Борис Хлебников: иестный диалог, [online], http://gazeta.sfukras.ru/node/2145, [28.09.2016].

Хлебников Б., В нашей стране трудно научиться профессии, [online], http:// snimifilm.com/intervju/boris-khlebnikov-v-nashei-strane-trudno-nauchitsya -professii, [28.09.2016]. 
DRIFTING TOWARDS HAPPINESS? BORYS CHLEBNIKOW'S FILMS

S U M M A R Y

The article presents the creative output of one of the most renowned representatives of the original cinema in Russia. It concentrates on Borys Chlebnikow's four feature films. The director, on the basis of the protagonists' structure and presented issues, shows his vision of contemporary Russia - the people's mentality, hopes and disappointments. 